\title{
Heta Kaisto
}

FM, Taiteen laitos, visuaalinen kulttuuri, Aalto-yliopisto

\section{Katja Lautamatti}

TaM, Elokuvataiteen ja lavastustaiteen laitos, Aalto-yliopisto

Aalto-yliopiston tohtoriopiskelijat Heta Kaisto ja Katja Lautamatti tekivät radioteoksen "Satavuotias yö" (2018), joka julkaistiin Yle Radio 1:n Radio Variaatiossa sunnuntaina 6.5.2018. Radioteos on molempien väitöstutkimusten taiteellinen osuus. Teos on osa laajempaa monialaista Koneen säätiön rahoittamaa hanketta "Hysteeriset oireet - Suomen sisällissodan ylimääräiset liuskat", jossa tutkitaan taiteen ja journalismin keinoin sisällissodan arkistoja. Teos on kuuneltavissa Yle Areenassa: https://areena.yle.fi/14400474

\section{Satavuotias yö: radioteos sisällissodan muistotietoarkistoista}

\begin{abstract}
Ylimääräinen liuska. En mene takuuseen, että ne olisi ihan alkuperäisen tekstin mukaan amalisoituja, sillä ne ovat vain muistista kirjoitettuja ja siitä on jo pitkä aika. Ne arvotukset jotka olen tässä ratkaissut ovat samoin muistissa säilynyt jo lapsuusvuosilta. ${ }^{1}$
\end{abstract}

Ylläolevan sitaatin antoi lukuohjeeksi muuan maanviljelijä, joka osallistui kirjeitse Suomalaisen Kirjallisuuden Seuran keruuseen 1960-luvulla. Keruun aihe oli Suomen sisällissodan muistot ja perinnetieto. Tämä SKS:n aineisto sai meidät, kaksi taiteellisen väitöstutkimuksen tekijää, arvioimaan omaa taiteellista työskentelyämme ja siihen osallistuvan teorian perustaa.

Työmme on vielä kesken, mutta jo nyt voimme hieman tarkastella omaa matkaamme kuuntelijoina. Yritämme tässä artikkelissa avata, millainen voisi olla kuunnelma kuuntelemisesta. Tekstissä käymämme vuoropuhelu on osittain epämuodollista. Sen tarkoitus on osoittaa, millä tavoin taiteellisessa tutkimuksessa subjektiivinen punoutuu osaksi prosessia.

\section{Tuhon teoria}

Työskentelymme lähtökohtana oli jaettu teoreettinen kiinnostus tuhon historiaan ja tietämisen tapoihin. Tapasimme kirjoituskurssilla ja aloitimme keskustelun väitöstutkimuksillemme yhteisistä kysymyksistä: niin muistamisen monimutkaisesta tapahtumasta tuhon äärellä kuin taiteen keinoista välittää sanatonta ja katkennutta.

\footnotetext{
1 SKS:n Kansanrunousarkiston keräys vuodelta 1966 (1917-18/4).
} 


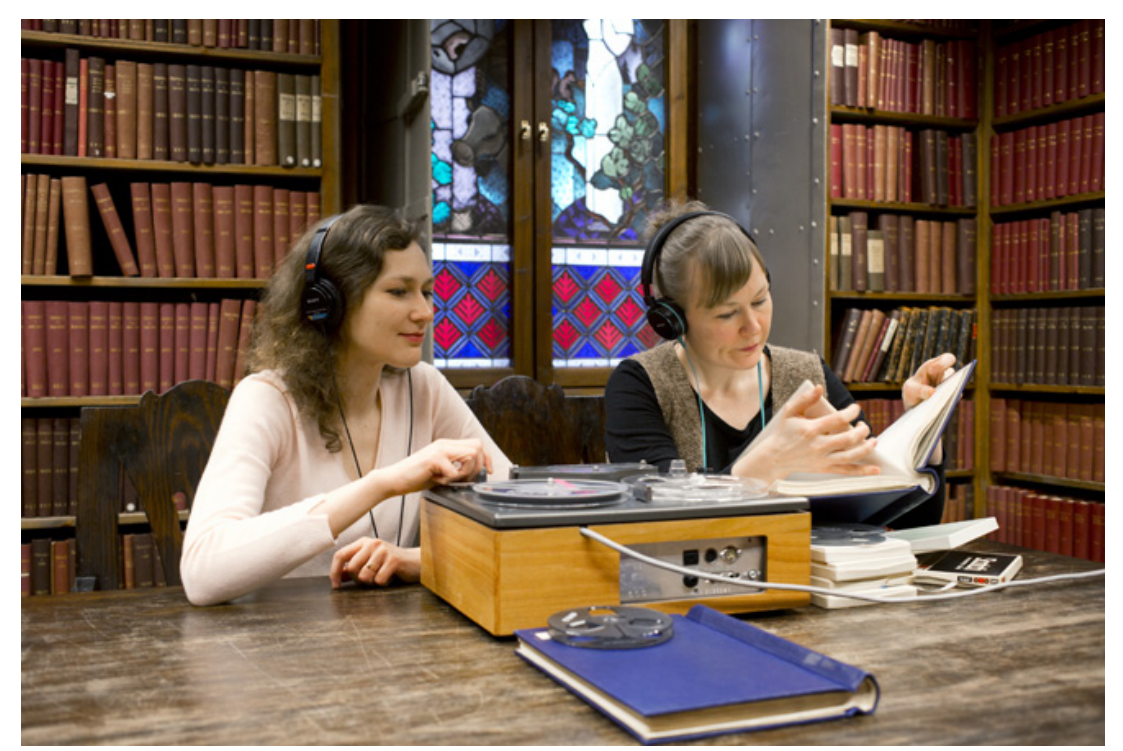

Heta Kaisto ja Katja Lautamatti sisällissodan muistitietokeräyksen aineistoon uppoutumassa. Kuva: Hanna Koikkalainen.

Heta soveltaa taiteellisessa tutkimuksessaan ranskalaisen Maurice Blanchot'n (1907-2003) filosofiaa ja pohtii tämän myöhäiskauden ajattelulle ominaista fragmentaarisen kirjoittamisen metodia. Blanchot sijoittuu toisen maailmansodan kokeneeseen filosofisukupolveen, joka lähti voimakkaasti haastamaan kirjoittamisen ja kielen kykyä käsittää holokaustin kaltaista tuhoa, joka pakenee kaikkea ajattelua ja tietoa. Teoksessaan L'écriture du désastre Blanchot tutkii tuhoa esittämällä sellaisen filosofisena tekstinä. Teoksessaan hän asettaa rinnakkain väitteitä, kysymyksiä, näkökulmia, vahvistuksia, pyöristyksiä, keksittyä ja totta, kunnes nämä pienet, lyhyet tekstit luovat fragmenttien sijaan kokemuksen fragmentaarisesta, joka välittyy vahvana epämukavuutena ja hämmennyksenä lukijalle. Tutkimuksessaan (Thunder and Silence: Disaster and Maurice Blanchot's Vision of Poetics) Heta tarkasteleekin taiteen keinoja filosofian kirjoituksessa Blanchot'ta mukaillen.

Katjan taiteellisen väitöstutkimuksen (Cinema of the absent - How to record the nothing) lähtökohtana on Libanonin sisällissodan (1975-1990) jälkeinen taide ja ajattelu johon muun muassa Blanchot'n perintö säteilee. Kiinnostavaa on erityisesti se, miten elokuvan keinoin Libanonissa on käsitelty kysymystä poissaolevasta tai latentista, kun klassinen dokumentti- ja fiktioelokuva eivät enää pitkittyneen sisällissodan myötä ole pystyneet antamaan muotoa ja kieltä tuhon kokemukselle. Elokuvantekijänä Katjaa kiinnostaa ajatus elokuvasta meediona; välineenä jonka kautta voi tallentaa sen mikä ei jätä jälkiä, sen mikä on poissa.

Likipitäen ensimmäisistä keskusteluistamme virisi ajatus yhteistyöstä. Lopputulema on noin 60-minuuttinen radioteos Satavuotias yö. Radioteos rakentuu pääosin äänitteistä, joissa on Suomen sisällissodan kokeneiden ihmisten haastatteluja, tai ehkä pikemminkin puhetta ja ääniä.

\section{Ääni ja katkoksen kokemus}

Aloittaessamme yhteistyön meille oli siis jo tuttua holokaustin ja Libanonin sisällissodan jälkeinen taideteoria ja ajattelu sekä siihen kytkeytyvät taiteen ja kerronnan keinot. Huomasimme, että molemmilla oli tarve tarkastella tuhon teoriaa oman kulttuurin kontekstissa: halusimme tutkia, miten myös Suomen sisällissodan kaltaiset tapahtumat voidaan nähdä historian katkoksina, joita perinteinen historiankirjoitus 
ei tavoita. Koska molemmat olemme myös taiteilijoita ja teemme taiteellista tutkimusta, oli ilmeistä, että teemme yhdessä taiteellisen projektin.

Pohdimme kahvikupin äärellä mikä haastaisi työmuotona meitä eniten. Molemmilla oli haave tehdä puhtaasti ääneen ja arkistomateriaaleihin perustuva teos, kuten radiokuunnelma. Ensinnäkin ääni tuntui tavalta päästä irti sellaisista audiovisuaalisen median konventioista, jotka liittyvät arkistokuvaan ja historiankirjoittamiseen, tai joissa tähdätään eheään, lineaariseen narratiiviin. Ääniteos mahdollistaisi katkoksen kokemukset. Lisäksi sen avulla voi luontevasti vaihtaa ja sekoittaa näkökulmia ja pohtia moniäänisyyttä.

Taiteellinen tutkimus tarkoitti meille myös mahdollisuutta lähestyä arkistoja itse kuuntelemisen tapahtumaa tunnustellen. Äänen kautta aukeaa tila, johon voi liittyä vahva fyysinen läsnäolon kokemus. Huoneessa auki oleva radio on hyvää seuraa. Televisio on ikkuna maailmaan, mutta radio oleilee tilassa ja luo intiimin kuuntelemisen tunnelman. Katjaan vaikuttivat muun muassa media-arkeologian tutkimus, jossa on teoretisoitu juurikin sitä, miten menneisyyden äänen tai äänitteen kautta poissaoleva voi palata "läsnäolevaksi" nykyhetkeen. Näissä käsitteissä on kiinnostavaa se, miten ne hahmottavat muistin suhdetta materiaan, epälineaariseen ajan kokemukseen ja erityisesti ääneen.

Heta taas pohti äänen vaikeaa roolia filosofian historiassa, jossa ääni on vuosituhansien ajan koettu hankalana tapana lähestyä ajattelua. Silmä on saanut melko rauhassa rakentaa maailmaa ihmisen ulkopuolella, mutta ääni on usein koettu tunkeutuvana ja häiritsevänä - eräänlaisena sisäisenä kokemuksena. Se on jäänyt täten liian epämääräiseksi ja henkilökohtaiseksi, jotta sen pohjalle voisi rakentaa yleiseen kokemukseen perustuvaa tietoa. Aistit myös arvottavat asioiden todistusvoimaa arkisessa kielessämme: silminnäkijyys on vahvempi peruste todistajuudelle, kun taas kuulopuhe herättää epäluulon. Mitä tämä kaikki voisi tarkoittaa kun kuuntelemme suomalaisia miehiä ja naisia aikojen takaa?

\section{Vaienneet arkistot}

Tavatessamme Katja oli vastikään hakenut lyhytelokuvia Mannerheimit 1-5 (2015) varten Carl Gustav Mannerheimiin liittyviä arkistomateriaaleja. Hänen mieleensä oli jäänyt tapaaminen valokuvataiteen museon tutkijan Jukka Kukkosen kanssa ja lausahdus siitä, kuinka tiettyjä kuvia Mannerheimista ei ole "toistaiseksi katsottu aiheelliseksi käyttää" sekä pohdinta niistä prosesseista, joilla tietyt kuvat nousevat ikonisiksi. Esimerkiksi tapaan kuvata ja esittää Mannerheim on punoutunut historian saatossa erilaisia intressejä. ${ }^{2}$

Mannerheimin kautta aukesi luonnollisesti kysymys myös kuvista, joita sisällissodasta on "katsottu aiheelliseksi käyttää". Kukkonen mainitsi myös äänitearkistot, joita oli itse ollut aikoinaan keräämässä Suomalaisen Kirjallisuuden Seuralle. Näitä sisällissodan silminnäkijoiden haastatteluja ei hänen tietääkseen oltu julkaistu. Jalkauduimme vihjeen perässä kansanrunousarkiston perinteen ja nykykulttuurin kokoelman kelanauhojen äärelle. Selvisi, että tutkija Ulla-Maija Peltonen oli käyttänyt haastatteluja lähteinä tutkimustyössään, mutta varsinaisia nauhoituksia ei todella oltu aiemmin julkaistu. Heti ensimmäisestä kuuntelukerrasta äänet veivät mukanaan.

\footnotetext{
2 Katja Lautamatin ja Jukka Kukkosen keskustelu Suomen valokuvataiteen museolla 18. heinäkuuta 2014.
} 


\section{7-1918-muistotietoaineisto}

1917-1918-muistitietokokoelma on ollut syntyessään ristiriitainen. Sisällissodan jälkeen historian kirjoittivat voittajat. Punaisten muisto oli käytännössä kielletty ja vaiettu. Kirjassaan Muistin paikat: Vuoden 1918 sisällissodan muistamisesta ja unohtamisesta Peltonen näyttää kuinka häviäjien haudat sijaitsivat piilossa, useimmiten metsissä, joissa ne merkittiin esimerkiksi risti- tai karsikkopuilla, viiltämällä puun kaarnaan risti (Peltonen 2003, 191). Puut olivat eräänlaisia eläviä muistomerkkejä, jotka väistämättä katosivat: ajan saatossa puita kaadettiin tai kaarnan viillot kasvoivat umpeen.

1960-70-luvuilla valkoinen ja punainen totuus vihdoin törmäsivät, osin kaunokirjallisuuden ansiosta. Häviäjien historiaa ryhdyttiin kartoittamaan ja keräämään perinnekyselyiden ja muistotietokeräysten kautta, myös SKS:ssa, jossa vuonna 1965 nuoret folkloristit lähettivät likipitäen kaikkiin Suomen sanomalehtiin keruuilmoituksen. He myös matkustivat maakuntiin ja koteihin haastattelemaan entisiä vankeja, taistelijoita, upseereita, punaisia, valkoisia, emäntiä, äitejä, siviilejä ja niitä, jotka olivat nähneet sodan lapsen näkökulmasta. Monet haastateltavat olivat jo hyvin vanhoja, useat syntyneet 1880-luvulla.

Keräyksen tuloksena seura sai sadoilta kansalaisilta yli 15000 sivua muistiinpanoja ja yli 100 tuntia haastatteluja: valtava aineisto, joka ei monelta osin istunut olemassa oleviin historiantutkimuksen kategorioihin. Mukana oli uskomustarinoita, lauluja ja erityisen paljon aavemaisia tarinoita teloittajista ja teloitetuista.

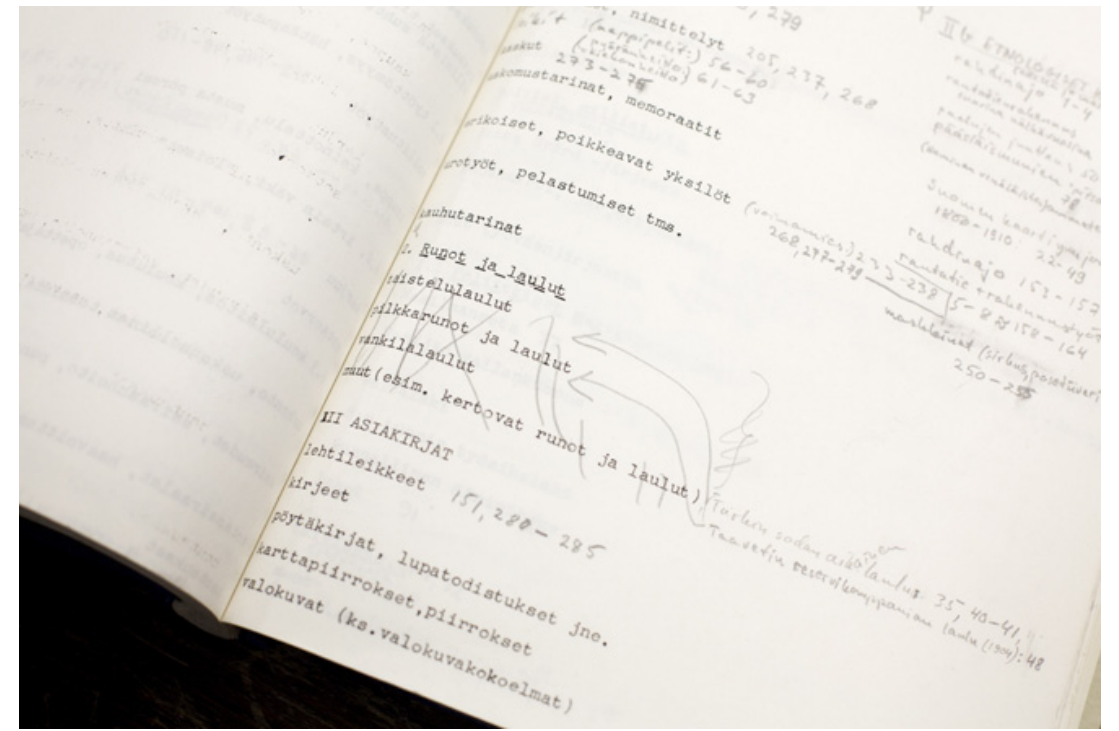

SKS:n arkistoaineistot on luokiteltu paitsi asiakirja- myös perinnekategorioiden näkökulmasta. Sisällissotaa koskeva muistitietokeruu tuotti valtavan aineiston paitsi muistelua myös uskomustarinoita, lauluja ja tarinoita. Kuva: Hanna Koikkalainen.

SKS:n historiikin kirjoittajan Kai Häggmanin mukaan vastauksien tulva kertoo siitä, että ihmiset olivat 1950-luvulla vihdoin ryhtyneet varovasti muistelemaan ja kertomaan lähihistoriastaan - huolimatta siitä, että sisällissodan muistaminen ei edelleenkään ollut vaaratonta. Häggman $(2015,183)$ kirjoittaa, kuinka monet kertoivat Väinö Linnan kirjojen vaikuttaneen siihen, "että he ylipäätään uskalsivat lähettää muistelmiaan seuralle, joka koettiin viralliseksi, valkoiseksi ja eliittiä edustavaksi".

SKS:n sisällä muistotietokeruuhanke herätti syvää vastarintaa. Helsingin yliopiston historian professori Eino Jutikkala julisti, että "tällaisella keruulla ei ole mitään merkitystä historiantutkimukselle". (Häggman 2015, 184.) Jutikkala jätti SKS:n 
johtokunnan ja käytti vaikutusvaltaansa, jotta tutkimuksessa ja opinnäytteissä ei hyödynnettäisi 1917-1918-muistotietokeruuainestoa. Aineisto vaikeni vuosikausiksi. ${ }^{3}$

Voi sanoa, että punaisten muisti oli patoutunut Suomessa 1960-luvulle saakka, ja nämä meidän edessämme vuonna 2016 pyörivät arkistonauhat todistavat hetkiä, joina tukahdetut muistot pääsivät vihdoin virallisesti kuulluiksi ja tunnustetuiksi. Tämä välittyy myös arkistonauhojen kuulijalle. Osa äänistä on tärkeitä ja juhlavia: "Kerron jotta tulee koko totuus julki", sanotaan painokkaasti. Tai purskahdetaan jännityksestä itkuun. Vaietut näkökulmat ilmenevät myös välttelyn ja jopa hourailun kaltaisena kiertelynä asioiden ympärillä. Tärkeässä roolissa ovat haastattelijat, jotka antavat kertojille tilaa, haastavat ja etenkin osoittavat myötätuntoa.

On pakahduttavaa, että vei toiset 50 vuotta, jotta äänet pääsevät kaikkien kuunneltaviksi.

\section{Kuuntelemisen työ}

Ranskalainen taidehistorioitsija ja filosofi Didi Huberman on sanonut, että arkistoa ei voi ihailla eheänä kokonaisuutena, vaan siihen pitää astua kuin metsään. ${ }^{4}$ Hubermanin ajatus on ohjannut meitä pohtimaan sitä, kuinka arkisto ei ole abstraktio vaan sidottu materiaalisuuteensa. Muisti kiinnittyy muistiainekseen, ottaa sen muodon ja ohjautuu sen läpi: kielen ja sanojen, kuvan ja äänen, kiven ja puun, minän ja toisen.

Astuimme arkistoon kuin metsään, kun saimme listan kelanauhoista, joita ei oltu digitaalisesti luetteloitu tai translitteroitu. Päätimme, että ainoa tapa edetä on kuunnella ja ääniaineisto kokonaisuudessaan läpi, laskujemme mukaan liki 120 tuntia äänitettyä puhetta. Kuuntelemiselle ei ollut oikotietä, sillä Nagra-nauhoja ei voi selailla kursorisesti. Kuuntelimme kaikki haastattelut arkistossa saman pöydän äärellä. Meillä molemmilla oli kuulokkeet, mutta istuimme vierekkäin. Toisen läsnäolo oli sanatonta mutta aktiivista.

Nauhojen haastattelut on tehty kertojia liiemmin ohjailematta. Äänitysten taustalla kuuluu arkinen tila ja elämä: lasten ääniä, ovikellon rimpautus, joka keskeyttää haastattelun, samassa pöydässä istuvan naapurin lisäykset tarinaan, paperipussien rapistelua, kahvinjuonnin ääniä, liikenteen pauhu tai puutarhan linnut. Kuuntelijoina herkistyimme kaikelle "ylimääräiselle": kärpästen surinalle, junapillin vihellykselle, vinkuville keuhkoille, puheen hiipumiselle vaikean asian edessä, yölle joka laskeutuu puutarhaan (jonka haastateltava lausuu ääneen), kilinälle, joka syntyy kun vanha nainen hämmentää lusikalla kahvia tai sytyttää tupakan aivan mikrofonin vieressä. Vanhempi nainen joka keskeyttää moneen kertaan kertomuksensa ja vaikertaa. Laulu jonka sanat menevät väärin uudestaan ja uudestaan. Kaverukset, joiden höpötyksestä ei saa mitään selvää. Aviomies, joka kuiskuttaa vaimon korvaan apua. Erilaiset hiljaisuudet tuntuivat merkittäviltä.

Kerronnan eri tasojen lisäksi huomiomme kiinnittivät myös muut äänen ulottuvuudet. Varsinaisen puheen lisäksi nauhuri on tallentanut sellaiset taustaäänet, kehon liikkeet, huokaukset ja kuiskaukset, joita ihmiskorva ei yleensä rekisteröi: koneen itsensä tuottamat narinat ja vihellykset, sekä toisinaan nauhan uusiokäytöstä joh-

\footnotetext{
${ }^{3}$ Meille kuvailtiin aineiston olleen SKS:n kannalta ongelmallinen vielä 1990-luvulla. Lisäksi hyvin käytännöllinen syy ääniteaineistojen vaikenemiseen on ollut äänittämisen helppous. Nauhoja kertyi SKS:n kansanrunousarkistoon vuosikymmenien aikana niin paljon, että resurssit eivät riittäneet niiden luettelointiin tai litterointiin ja puhe oli "hautautumassa arkistojen uumeniin". Ks. Häggman 2015, 117.

4 "You cannot have an embracing view of an archive, in the way you can have an embracing view of an atlas, you have to enter a forest." Huberman 2012.
} 


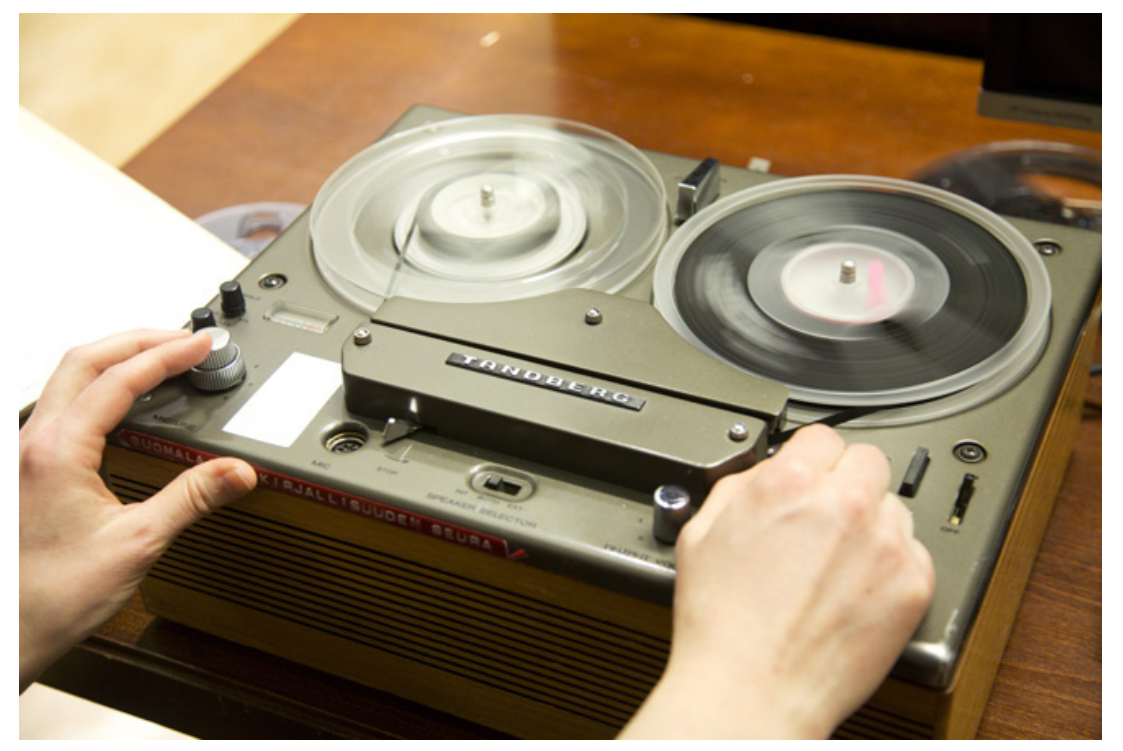

Teosta varten kuunneltiin läpi koko yli 100-tuntinen nauhoitemateriaali. Niille tallentuneiden tarinoiden lisäksi nauhat itse ovat osa menneisyyttä ja kulttuurihistoriaa. Kuva: Hanna Koikkalainen.

tuvat taustan "haamuäänet". Kaikki tämä puheen lisäksi tallentunut ainutlaatuinen "melu" muodostaa media-arkeologian keskustelua lainaten narratiivin "raunion". Puheen lisäksi itse mediateknologia, tässä tapauksessa kelanauhuri, tallentaa kielen ja diskurssin ympäristössään, ja näin myös viittaa siihen mikä jää kognitiivisten merkitysten ja narratiivin ulkopuolelle (Wolfgang Ernst, sit. Parikka 2011, 257).

Kelanauhat olivat tärkeitä kuuntelutyön kannalta myös siksi, että niillä oli konkreettisina esineinä oma historiansa ja läsnäolonsa. Huomioimme, että juuri nämä samat nauhat, joita onneksemme saimme kuunnella, olivat osallistuneet nauhoitustapahtumaan. ${ }^{5}$ Tämä ajatus, yhdistettynä analogisen äänen syvyyteen, synnytti intensiivisen, fyysisen kokemuksen. Nauhojen materiaalisuus välitti äänet toisella tavalla paikalle. Ihmiset tuntuivat istuvan vieressämme. Nykytaiteen ja mediaarkeologian piirissä on pyritty hahmottamaan ja teoretisoimaan tätä ilmiötä.

Viviane Sobchack hahmottaa menneen mahdollisuutta palata läsnäolevaksi nykyhetkeen (eng. re-presencing the past) kehollisena tapahtumana, jossa median materiaalisuus sekä taju sen ainutlaatuisuudesta (kenties aurasta) ja sijoittumisesta aikaan voi muistuttaa meitä jostakin toisesta. Hän lainaa norjalaisen arkeologin Bjornar Olsenin ajatusta: unohdettujen historialla ei ole narratiivia, vaan se tulee meille hiljaisina, käsin kosketeltavina, karkeina materiaalisina jäänteinä (Sobchack 2011, 323). Sobchackin jäljillä on pohdittu esimerkiksi äänimonumentin käsitteen kautta nimenomaan arkistoääntä ja sitä, kuinka kohtaamisessa sen kanssa olennaista ei välttämättä ole enää puheen historiallinen ja kognitiivinen sisältö, vaan äänestä aukeavat itsenäiset merkitykset ja vaikutelma äänen fyysisestä läsnäolosta (eng. sound monument, Dotto 2016).

Juuri fyysisten vaikutelmien ja kehon kautta kiinnitimme pian huomion itseemme kuulijoina. Havahduimme kuuntelemisen työläyteen: läheskään kaikki äänet eivät olleet miellyttäviä kuunnella. Osa puudutti, osa puistatti ja osa jäi vain vieraiksi. Ja vaikka pystyimme kelaamaan nauhoja taaksepäin ja tarkistamaan sanottua, jäi osa puheesta kuulematta epäselvän puheen tai oman väsymyksen vuoksi. Huomasimme, että kuuntelemisen fyysisyys on kokonaisvaltaista ja ajoittain epämukavaa. Se

\footnotetext{
5 Vasta kuuntelun jälkeen paljastui, että kenttätöissä käytettiin nauhojen halvempaa laatua, ja kenttätaltioinnit kopioitiin parempilaatuisille arkistonauhoille, joita kuuntelimme arkistossa.
} 
pitää sisällään erilaisten asentojen ottamista, keston sietämistä - vaikkapa silloin kun joku hakkaavalla äänellä lukee paperista valmiiksi kirjoitetut taistelumuistelmansa päivämäärineen.

Koska emme voineet nähdä ihmisiä, kuvittelimme heidät. Muistiinpanoissamme on monia kysymyksiä kuten "Onko nainen humalassa? Vai puhuuko hän hitaasti vain vanhuuttaan?" Keräsimme mielikuvamme ja tuntemuksemme sitä mukaa ja sellaisina kuin ne tulivat, ja myöhemmin pohtiessamme työskentelymme eri vaiheita ovat muistiinpanot olleet suuresti avuksi eräänlaisina kategorioina äänille. Samalla ne ovat auttaneet meitä havainnoimaan itseämme kuuntelijoina ja astumaan kuulemisen epämukavuuden tilaan - mukaan lukien siihen, missä kuulija ei tunne ylpeyttä itsestään.

Työmme edetessä luovuimme kasvavassa määrin kontrollista ja kuljimme aineiston ehdoilla, sen meille osoittamaa polkua pitkin.

\section{Kuunnelma kuuntelemisesta}

Kuuntelemisen kokemus johti pohdintaan kuunnelman mahdollisista taiteellisista, metodisista ja dramaturgisista ratkaisuista. Mietimme ja työstimme kysymystä kuunnelman ja oman radioteoksemme kertojaäänestä, johon muun muassa Aleida Assmanin (2015) empaattisen kuuntelijan käsite ja uudentyyppinen kertojaääni on vaikuttanut. Siinä missä historia tavoittelee totuutta, muisti etsii identiteettiä ja empaattinen kuuntelija pyrkii asettumaan todistajaksi todistajalle. Empaattisen kuuntelemisen kautta arkisto muuntuu eläväksi muistiksi, joksikin, joka on uudelleen koettavaa, vaikka ei alkuperäinen kokemus.

Kuuntelijan roolin, ja tuhosta kirjoittamisen työn, voi hahmottaa myös Hannah Arendtin ajattelun kautta, sietämisen ja keston näkökulmasta: kuuntelija mahdollistaa tilan, jossa tarinat kerrotaan uudestaan ja uudestaan. Yksittäinen historiallinen kertomus tai analyysi ei nimittäin Arendtin $(1955,21)$ mukaan ratkaise suhdettamme menneeseen tapahtumaan, tai lievennä tuskaa. Jotta voimme ymmärtää "mitä tapahtui", meidän pitää toistaa tarina menneestä yhä uudestaan siihen saakka, kunnes etäisyys tapahtumiin ja varsinainen historiankirjoitus syntyy. Tähän menee aikaa. On runoilijan tai historioitsijan tehtävä sietää tarinoita ja mahdollistaa niiden kuulluksi tuleminen.

Kuuntelemisen inspiroimina pohdimme myös radioteoksen kuuntelemiskokemusta laajemmin: Mitä jos luopuisimme kertojaäänestä ja sen sijaan yrittäisimme avata radioteokseen kuuntelemisen tilan? Millainen se voisi olla käytännössä? Millainen olisi kuunnelma, jonka kuuntelemiseksi on tehtävä töitä, pinnisteltävä, jopa petyttävä? Sietäisikö tavallinen radiokuuntelija epätietoon perustuvan kuuntelemisen yksinäisyyttä, joka ei tarjoa vastauksia, edes selityksiä?

Kertojaäänestä luovuttuamme aloimme pohtia, mikä muu äänielementti voisi ympäröidä arkistonauhoja ja kirkastaa niiden monia kerroksia. Jo varhaisessa vaiheessa kirjasimme ylös ajatuksen musiikin ja dokumentaarisen väliin sijoittuvasta ambient-äänimaisemasta, joka voisi syventää kuuntelemiseen keskittymistä. Hetalla oli kokemusta analogisista syntetisaattoreista ja hän tunsi jo jossain määrin niiden mahdollistamat äänimaailmat. Arkistonauhoihin jääneet rahinat ja nauhuriäänet muistuttivat häntä syntetisaattoreiden leikkisästä pulinasta, ja tarinat metsistä ja junavaunuista alkoivat soida hänen mielessään sähköisenä kohinana. Kokeiluun valikoitui Jonte Knifin suunnittelema analoginen syntetisaattori Knifonium. Sähköisen äänen orgaanisuus tuntui hyvältä lähtökohdalta jatkaa nauhojen luomaa tunnelmaa. 


\section{Kokemukset perinteeksi}

Muistotietokeruun organisoineiden folkloristien yksi lähtökohta ja tavoite oli selvittää sitä, kuinka sisällissodan omakohtaiset ja yksilölliset kokemukset ovat ajan myötä muuttuneet perinteeksi (Häggman 2015, 183). Huomasimme miten materiaaleissa toistuvat samojen kuvien ja sanojen erilaiset variaatiot. Ne kasvoivat ja vahvistuivat mielissämme eräänlaiseksi tietämykseksi sisällissodasta. Mädistä perunoista paistetut pannukakut ja hevosenkaviokeitto. Raajarikkojen ja keuhkotautisten vaellus Uralille. Leivät, jotka jäivät paistamatta, kun vihollinen tuli. Talo, jonka tapetit revittiin vihan vallassa. Kuuseen rakennettu asumus, johon oli raastettu peittoja ja vällyjä. Vanhapiika, joka piilotti rahojaan metsään ja harhaili sodan jälkeen niitä etsimässä.

Edelleen huomioimme, kuinka kertomuksissa toistuvat absurdit ja keholliset piirteet toivat usein mieleen meille paljon tutummat holokaustikertomukset. Mies, joka kurotti janoisena sadevettä ja ammuttiin ikkunaan. Mies, joka lymyili ladossa ja kuuli joka päivä pihalta kuolemantuomionsa. Sekaisin menneet vangit, jotka kieriskelivät vankileirin lattioilla kuumeessa, pimeässä. Nälkiintynyt mies yritettiin murhata piimällä ja munilla.

Kuisma Korhonen $(2011,200)$ on huomioinut, kuinka useimmissa holokaustitodistuksissa korostuu nälän, kylmän, kivun ja väsymyksen läsnäolo, ja sankaritarinoiden sijaan selviytymistarinat ovat groteskeja ruumiillisten perustarpeiden täyttymisiä. Olemme pohtineet paljon aineiston sävyä ja miettineet, mistä on voinut johtua meidän molempien intuitiivinen tunne sen eräänlaisesta keveydestä. Yksi syy tälle voi olla kertomuksissa toistuva äärimmäisyys yhdistettynä kertojien hyväntuuliseen tai lakoniseen kerrontaan. Materiaali ei tarjoa tuhon esittämiselle ja kertomiselle yhtä sävyä tai nuottia. Haluamme kaikin tavoin suojella ja korostaa tätä aineiston ominaislaatua.

Läpi työskentelymme metsä on ollut kuunnelman yksi mahdollinen dramaturginen elementti. Metsä toistuu sisällissodan tarinoissa piilopaikkana, teloituspaikkana, pakoreittinä ja se on myös ollut punaisten hautojen maisema monta vuosikymmentä. Metsä viittaa siihen mitä ei näytetä, mitä ei voida näyttää. Se on ajaton tila, johon kaikki palaa, kuten László Nemesin elokuvassa Son of Saul (2015), missä Auschwitzin keskitysleirin kaoottinen melu lopussa vaihtuu metsän hiljaisuuteen.

\section{Kasvaa todistajaksi todistajalle}

Maurice Blanchot näki tuhon kirjoituksessa filosofian mahdollisuuden: mikä ei ole ajateltavissa on kuitenkin lähestyttävissä ja mahdollista esittää. Libanonissa sodanjälkeinen sukupolvi on esittänyt perustavanlaatuisia kysymyksiä muistamisen ja unohtamisen dynamiikasta sekä historiankirjoittamisen ehdoista ja edellytyksistä. Libanonilaisen Jalal Touficin $(2000,115)$ käsite withdrawal of tradition past a surpassing disaster (vapaa käännös: "perinteen vetäytyminen ylimenevän tuhon jälkeen") kuvailee, Blanchot'a mukaillen, kuinka tietynlaiset katastrofit jättävät kirjat ja monumentit materiaalisella tasolla ehjiksi, mutta iskevät perinteeseen joka vetäytyy. Touficille Blanhot'n tuho on totaalinen ja meidän ulkopuolellamme, mutta hänen omassa ajattelussaan tuho määrittää yhteisön. Tuho on meidän asiamme, ja kirjailijoina, elokuvantekijöinä ja ylipäätään taiteilijoina vastuullamme on havaita ja esittää tuho ja sen aiheuttama katkos ja poissaolo (Toufic 2009, 63).

Radioteosta työstäessämme palasimme kuin vahingossa Blanchot'n perusajatukseen teoksen persoonattomuudesta: kun kirjoittaja poistuu, alkaa teksti puhua itsenään (esim. Blanchot 2003, 190-191). Kuuntelemisen työ on tarkoittanut meille ennen kaik- 
kea mahdollisuutta ajatella tuhoa omalla kielellämme. ${ }^{6}$ Äidinkieli, erilaiset murteet ja sanat, joista toiset yhä käytössä, toiset jo poistuneet, palauttavat tapahtumat omaan kehoon. Arkisto - meidän metsämme - on ollut kuuntelemisen paikka, jossa olemme ohjaajina luopuneet hallinnasta ja antaneet äänten ilmaisuvoiman, kohinoiden ja erilaisten merkitysten ympäröidä meidät ja asettua paikoilleen mahdollisimman levollisesti ja omalla painollaan.

\section{Lähteet}

Arendt, Hannah (1955) Men in Dark Times. New York: Harvest book.

Assmanin, Aleida (2015) The Empathetic Listener and the ethics of storytelling. Esitelmä konferenssissa Ethics of Storytelling: Historical Imagination in Contemporary Literature, Media and Visual Arts. (University of Turku 4-6 June 2015).

Blanchot, Maurice (2003) Kirjallinen Avaruus. Käänt. Susanna Lindberg. Helsinki: ai-ai.

Blanchot, Maurice (1995) The Writing of the Disaster. Käänt. Ann Smock. Lincoln \& London: University of Nebraska Press.

Derrida, Jacques (2005) The Poetics and Politics of Witnessing (Poétique et politique du témoignage, 1986). Teoksessa Sovereignties in Question. The Poetics of Paul Celan. Toim. Thomas Dutoit \& Outi Pasanen. Käänt. Outi Pasanen. Fordham University Press, New York.

Dotto, Simone (2016) Archival (Sound) Recordings. Sonic Documents, Monuments and Artifacts in Rodolfo De Angelis' Collection. Esitelmä konferenssissa Imaging the Past/Collecting the Future (Lucca, 22-25 June 2016).

Huberman, Didi (2017) "Histoires de fantômes pour grandes personnes" (Le Fresnoy, Studio national des arts contemporains 31.11.2012). Videodokumentaatio, Ashkal Alwan, Beirut 2.11.

Häggman, Kai (2015) Pieni kansa, pitkä muisti - Suomalaisen Kirjallisuuden Seura Talvisodasta 2000-luvulle. Helsinki: Suomalaisen Kirjallisuuden Seura.

Korhonen, Kuisma (2011) Lukijoiden yhteisö. Helsinki: Avain.

Parikka, Jussi (2011) Mapping Noise - Techniques and Tactics of Irregularities, Interception, and Disturbance. Teoksessa Media archaeology: Approaches, applications, and implications. Toim. Erkki Huhtamo \& Jussi Parikka. Berkeley, Calif.: University of California Press.

Peltonen, Ulla-Maija (2003) Muistin paikat: Vuoden 1918 sisällissodan muistamisesta ja unohtamisesta. Helsinki: Suomalaisen Kirjallisuuden Seura.

Sobchack, Vivian (2011) Afterword: Media Archaelogy and Re-presencing the Past. Teoksessa Media Archaeology: approaches, applications and implications. Toim. Erkki Huhtamo \& Jussi Parikka. Berkeley, Los Angeles \& London: University of California Press.

Toufic, Jalal (2000) Forthcoming. Berkeley: Atelos.

Toufic, Jalal (2009) The withdrawal of Tradition Past a Surpassing Disaster. Forthcoming books.

\footnotetext{
${ }^{6}$ Myös itse kieli todistaa tuhoa, tästä puhuu muun muassa Jacques Derrida artikkelissa "Poetics and Politics of Witnessing", viitaten erityisesti Paul Celanin runouteen ja ajatukseen, että saksan kieli todisti holokaustin tapahtumia. Derrida 2005, 67-68.
} 